\title{
Do Smart Citizens Make a Smart City? A Case Study on the Factors Influencing Citizen Behavior Using Lapor Sleman Online-Based
}

\author{
Helen Dian Fridayani ${ }^{1}$, Achmad Nurmandi ${ }^{2}$ \\ ${ }^{1}$ Master of Government Affairs and Administration, Universitas Muhammadiyah Yogyakarta, \\ helen.2016@pasca.umy.ac.id. \\ ${ }^{2}$ Professor at Master of Government Affairs and Administration, Universitas Muhammadiyah \\ Yogyakarta,nurmandi_achmad@umy.ac.id.
}

\begin{abstract}
Indonesia is among the countries developing the concept of smart city. The national government envisions Indonesia 2030 which shall implement the smart city towards sustainable development. Many regions in Indonesia have already implemented the concept of smart city, but still on the level of smart government and smart technology, lacking on the smart citizen component of a smart city. This paper aims to analyze the citizens behavior of using technology on Sleman smart citizen 2021 through the lapor sleman mobile application. This research uses mixed method of quantitative and qualitative approaches in examining the data. The authors distributed 100 questionares and conducted interviews to the government which is department of communication and information, Sleman and the several community that ever use the lapor sleman application. The result of the study reveals the following: firstly, performance expectancy, social influence, and behavioral intention are three independent variables which affect the users' behavior. Secondly, the behavioral intention has the biggest significant effect on users' behavior. Thirdly, the citizen behavior of using technology has affect the making a smart citizen. Therefore, using technology in term of lapor sleman mobile application can make the citizens as active participants in public life, in terms of social cooperation, freedom of expression and flexibility. However, there are still many problems in the use of lapor sleman mobile application such as the limited access to only android smartphones, lack of technical know-how, and people's reluctance to use the lapor sleman mobile application.
\end{abstract}

Keywords: Citizen, behavior, smart citizen, technology, lapor sleman mobile application.

\section{INTRODUCTION}

Indonesia is among the countries which is developing the concept of smart city (smartcityindonesia.org, 2018). The elements of the smart city concept include the following: smart government, smart education, smart building, smart mobility, smart technology, smart healthcare, smart infrastructure, smart development planning, smart energy, smart security and smart citizen (Siti, 2018). All these elements are interconnected. Hence, the concept of smart city will not run effectively and efficiently, if not being supported by smart citizens. The concept of smart citizen is about the synergy between technology and the citizens; without smart people, smart city development will not run well. Intelligent societies are urgently needed 
as the main driving force of the digital economy which is expected to produce a change in the future of the economy (smartcityindonesia.org, 2018). According to Pew Research (2014) in Comptutrade Technology International (2016), a citizen or community who often use the internet will most likely to be more productive. The more connectivity people have, the more information they can get. This makes wireless technology as an essential component in building smart citizens.

In Yogyakarta, some districts have implemented smart city/smart regency. In this study, Sleman Regency which is one of the pilot project of Ministry Of Communication and Informatics of Republic Indonesia in terms of application smart city (Indera, 2018). On 2017, Sleman was awarded by Indonesian Government Awards (IGA) 2017 as a district committed to continue the implementation of smart city and 24 other cities/districts in Indonesia (slemankab.go.id, 2018). On the same year, Sleman has completed five quick win in one data of SMEs (Small Medium Enterrprise, namely; smart room, Lapor Sleman, Sleman Creative House, and Sleman Creative Space (slemankab.go.id, 2018). Regent Sri Purnomo of Sleman Regency is fully committed to make Sleman as Smart Regency in 2021, which is based on the application of integrated information and communication technology. Strategy and road map of smart city implementation is found in the Regional Medium Term Development Plan (RPJMD) of Sleman 2016-2021. The implementation of good information technology will ultimately support the process of determining the direction and policy of an organization, as well as the Sleman regency. This is in accordance with the vision of Sleman Regency, to quote "The realization of a more prosperous Sleman community, Independent, Cultured and Integrated system to the Smart Regency in 2021" (RPJMD Sleman 2016-2021). Specifically, the policy direction of Smart Regency development in Sleman Regency Government is focused on several aspects as follows:

1. Service, emphasis on technology utilization and improvement of human resource commitment to realize excellent service toward Sleman Smart Regency.

2. Internal efficiency, simpliflying procedures, standardization, emphasis on time efficiency and cost of unnecessary pruning/bureaucratic procedures, as well as standard setting.

3. Networks/inter-governmental institutions, emphasis on establishing connections between government institutions for resource sharing, particularly related to data resources (RPJMD Sleman, 2016-2021). 
The application that is often used by the people in Sleman is Lapor Sleman mobile application based on the staff of the department of communiaction and information in Sleman (Sleman Report, 2018, interview). Every year there are about 1500 complaints forwarded to the government through Lapor Sleman mobile application. The functionality of the Lapor Sleman varies. In general, this application is used as a communication medium which bridge the community and the regency government to the various problems occurring in Sleman. This include things that can be reported, among others, ranging from the condition of damaged roads, public infrastructure, problems of handling waste, licensing, criminal and so forth (Ariya, 2018). Hence, this will pave the way for developing high tech adaptation in Sleman and can be a pilot for other districts in the rest of the cities and regencies in the Yogyakarta region. Subsequently, technology-aided citizens lead to smart city with smart citizens. Moreover, this paper analyzes the factors that influence the citizen behavior using lapor sleman application and how does citizens behavior affect the Sleman smart citizen 2021 vision.

\section{THEORETICAL OVERVIEW}

There are key components of smart city which set to clarify the relation between the factors and applications (Nam and Pardo, 2011). First, technological factors may transform a regency or city into a smart city with the significant use of information and communications technology (ICT). While technological infrastructure is necessary, it is not a sufficient indicator of a functioning smart city (Baldascino and Mosca, 2016); (Nam and Pardo, 2011). This view refers to the integrated network technology that provides ICT system for the public organization, particularly as alternative action related to accessibility and availability information system. For example, internet-based government is capable to transform itself from old government to new government (Nam and Pardo, 2011)

Secondly, human capital and education have important implications to the process of development. It addresses the other factors such the roles of human actions, social capital, and education in smart city. The effect of technology could be mapped using several components of human capital, i.e. human conduct, human subjectivity, and functioning human life. Thus, it could be deduced that the development of smart 
people is linked to the quality of human and social capital, improving public participation, creativity, cultural, and public knowledge. Smart people are invested with norm and morals which can address ways to building a smart city (Vanolo, 2014).

Third, institutional factors have implication to government structures, governmental powers, and regulatory process that impact a smart city. The assessment on regulatory rules in the institutionalization of a smart city for instance, depends on how it is approached, developed, and implemented by policy-makers. However, regulations and policies can bring solutions by changing the rules and institutions in aid of technology. In other words, the present of government support and governance is the main act to design and to implement a smart city (Vanalo, 2014). Nam and Pardo (2011) argued that institutions enable smart city to integrate transparent governance, strategic and supporting activities, networking, and partnership (Nam and Pardo, 2011).

For Palomo and Navio (2017), the development of smart city is related to governance network, with patterns of social relation and interaction among the actors, aimed to create good partnership interaction (Palomo and Navio, 2017). Governance network is characterized by the following:

\section{1. formalized coordination pattern,}

2. organized network understanding,

3. regulated rules to improve the ability of decision making process,

\section{4. bind agreements and building informal relationships.}

Be that as it may, growing concern on sustainability issues is explored in the smart city concept. Examining the context of human capital for developing smart city is important to link better service and infrastructure through participatory governance (Ahvenniemi et al. 2017). Several studies have been conducted to have a more holistic approach in the study of smart city. A smart city brings together technology, government and society to achieve smart economy, smart environment, smart people, smart living, and smart governance (Ahvenniemi, et al. 2017); (Cocchia, 2014); (Travis, 2017); (Aelenei et al. 2016); (Garcia-Ayllon and Miralles, 2015); (Massana et al. 2017); (Holler et al. 2014); (Allwinkle and Cruickshank, 2011).

The methods of community participation have been tried and tested in controversial determinations (Bull et al., 2008) and transportation planning (Bickerstaff and Walker, 2005). Sovocool (2014) notes that there are three benefits to engage society 
using technology; firstly, democracy increases since all citizens have the right to participate and are represented in environmental decision-making; Secondly, communities are often more familiar with the local concerns of the people, and thirdly, greater acceptability can often achieved by involving those affected by the situation. Information technology is a platform to generate participatory processes from people in the community (Sovocool, 2014). Connecting data, people and knowledge, is the purpose of the platform serving as a node to build productive and open indicators and distributed tools, towards collective development of the city. Acceptance of information technology needs to be realized by members of the government and also the entire community to build a good country with good governance and adaptation to the technology-mediated era (Bull et.al., 2008).

This paper utilizes UTAUT theory to analyze the Acceptance of information technology in Sleman regency. Unified Theory of Acceptance and Use of Technology (UTAUT) is one of the latest technology acceptance models developed by Venkatesh et al (2013). UTAUT combines the successful features of eight leading technology acceptance theories into one theory. The eight major theories incorporated in UTAUT are the theory of reasoned action (TRA), the technology acceptance model (TAM), the motivational model (MM), the theory of planned behavior (TPB), the combined TAM and TPB, the model of PC utilization (MPTU), innovation diffusion theory (IDT), and social cognitive theory (SCT). UTAUT proved to be more successful than the other eight theories in explaining up to 70 percent of user variants. After evaluating all eight models, Venkatesh et al. found seven constructs that appear to be a significant direct determinant of behavioral intention or use behavior in one or more models.

The constructs are performance expectancy (PE), effort expectancy (EE), social influence (SI), facilitating conditions (FC), attitude toward using technology, and selfefficacy (Batara, 2017). After further testing, they found four major constructs that play an important role as a direct determinant of behavioral intention and use behavior, performance expectancy, effort expectancy, social influence, and facilitating conditions. While others are not significant as a direct determinant of behavioral intention. There are also four moderators: gender, age, voluntariness, and experience positioned to moderate the impact of the four major constructs on behavioral intention and use behavior. However in this study will not use the moderate variables. 
Based on the model of UTAUT theory, the authors proposed a new one research model as shown in Figure 1 below.

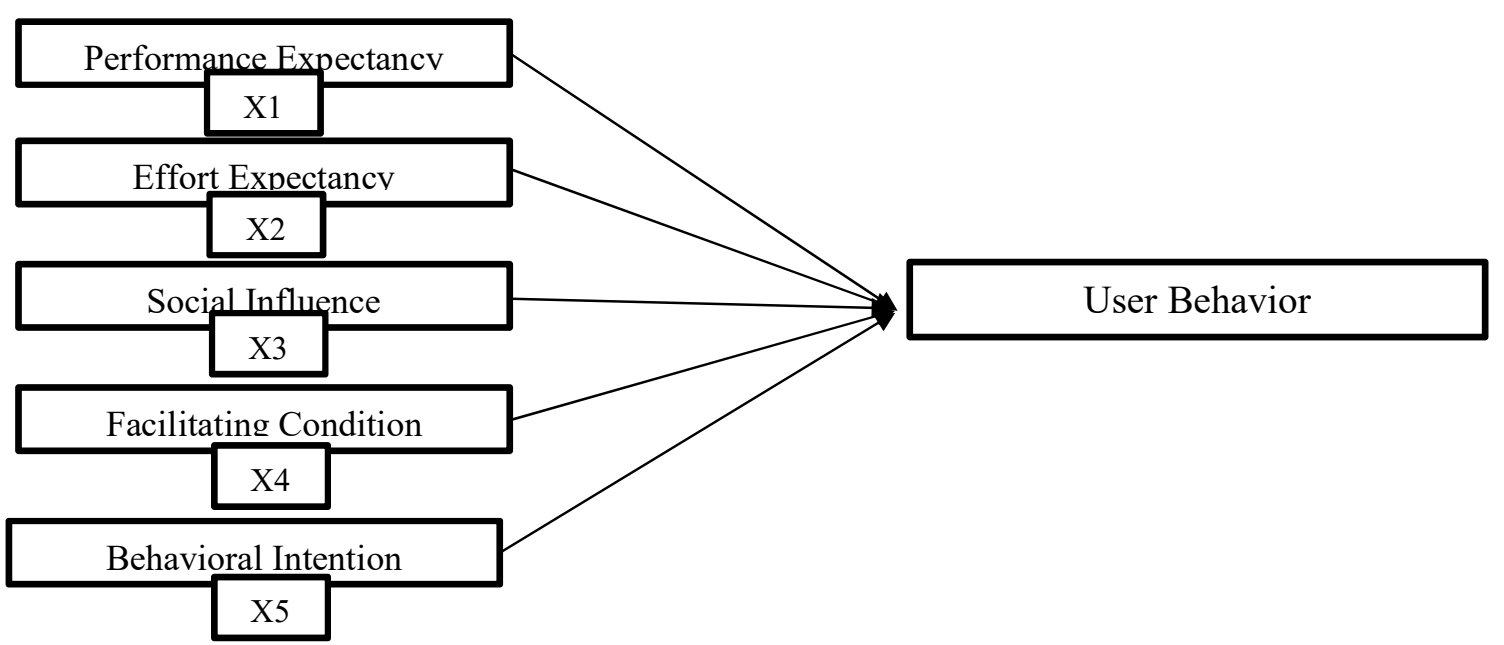

Figure 1. Research model. Source: Compiled by the author (Fridayani, 2018).

\section{Performance Expectancy}

Performance Expectancy as revealed by the studies of Yang, et.al., (2007); Song, et. al., (2008), and Qian, et. al., (2008) is one of the constructs of UTAUT which has a significant effect on behavior intention. Performance Expectancy is defined as the extent to which individuals believe that the use of a system will help them to achieve maximum performance in their works (Venkatesh et al., 2003). Ajzen (1991:181) mentioned that intention is one of the motivating factors which influences behavior. Behavioral Intention indicates the extent to which a person will use a particular technology in the future (Marhaeni, 2014). Performance expectancy in the use of technology is defined as how high a person, believes that using a system will help $\mathrm{him} /$ her to gain performance benefits at his/her job. The indicators used to measure are:

a. The usefulness of perceptions in the technology use of Sleman Smart Citizen is how far a person believes that using a particular system will improve the performance of his work.

b. The relative advantage in the technology use of Sleman Smart Citizen is how the capabilities of a system improve the performance of individual work.

c. The results outcomes are a relation to the consequences of behavior. Based on empirical evidence in the technology use of Sleman Smart Citizen, they are separated into performance expectations and personal expectations. 
H1: The performance expectancy has significant effect on users behavior

\section{Effort Expectancy}

Effort Expectancy according to Venkatesh et al. (2003) has a positive influence on Behavioral Intention. The same was expressed by Pahnila et al. (2011) stating that effort expectancy is one of the important factors in the acceptance of Tao Bao, Chinese eBay (Pahnila et.al., 2011). This was corroborated by the research of Foon and Fah's (2011) on Internet Banking adoption in Kuala Lumpur, which revealed that effort expectancy was one of the factors that directly affected Behavioral Intention (Foon and Fah, 2011). However the study from Tibenderana \& Ogao (2008); Qian, et. al., (2008), and Šumak, Polančič \& Heričko (2010) concluded that effort expectancy does not significantly influence behavioral intention. Effort Expectancy is the level of ease perceived by the users in using a system (Venkatesh et al., 2003). Effort expectancy in technology use is defined as the level of convenience associated with the use of a system. The indicators used to measure Effort Expectancy are:

a. Ease of use of perceptions is how far one believes that using a system will be free from difficult attempts.

b. Ease of use is how far using a perceived innovation is easy to use.

H2 : The effort expectancy has significant effect on users behavior

\section{Social Influence}

Social Influence is the extent to which a person perceives that other people around him or her (eg, family and friends) can influence him or her to use a certain technology (Venkatesh et al., 2013). According to the research of (Foon and Fah (2011), social influence has a significant influence on behavioral intention, it is also supported by a research conducted by Indrawati and Haryoto (2015) showing that social influence has a positive influence on behavioral intention. According to Venkatesh et al. (2003), social influence is the factor determining behavioral intention directly. While $\mathrm{Xu}$ (2014) argued that social influence is the most important determinant of the continuous intention. Social influence in technology use is defined as the extent to which an individual perceives interests believed by others who will influence it using a new system. The indicators used to measure social influence are: 
a. The subjective norm is the perception of a person that most people who matter to him think he or she should or should not do the behavior.

b. Social factors are the internalization of a person about the subjective culture of the reference group and the specific interpersonal agreement that a person undertakes with others in specific social situations.

H5 : The social influence has significant effect on users behavior

\section{Facilitating Condition}

Facilitating Conditions are defined as the extent to which an individual believes that organizational and technical infrastructures exist to support the use of a system (Venkatesh et al., 2013). A research by Foon and Fah (2011) stated that facilitating conditions are the factors influencing behavioral intention. In the UTAUT model, Venkatesh et al. (2013:162) added that the direct influence of facilitating conditions on behavioral intention. In contrast, the study of Indrawati and Haryoto's (2015) found out that there is no evidence to suggest that facilitating condition variables have a positive influence on behavioral intention. However, The results of this study are in line with the results of research by Al Awadhi \& Morris (2008), Foon \& Fah, (2011) which concluded that facilitating conditions has a significant effect on behavioral intention. Facilitating Conditions in technology use are defined as the extent to which one believes that organizational and technical infrastructure is available to support the system. The indicators used to measure facilitating conditions are:

a. Perceptual behavior control is a reflection of perceptions of internal and external constraints on behavior and includes self-belief, resource facilitation conditions, and technological facilitation conditions.

b. Facilitating conditions are objective factors in the environment in which the observers agree to make an action to be easy to perform, including the provision of computer support.

H5 : The facilitating condition has significant effect on users behavior

\section{Behavioral Intention}

According to $\mathrm{Wu}$ et al. (2012), Use Behavior measures the actual use frequency of a technology by the users. Use Behavior is measured from the actual frequency of a particular technology use (Venkatesh et al., 2003). The research made by Indrawati and 
Marhaeni (2015) found out that use behavior has a positive and significant influence on behavioral intention. In the study of $\mathrm{Wu}$ et al. (2012), it was found that behavioral intention is one of the variables having an influence on use behavior. This is followed by a research of Indrawati and Marhaeni (2015) revealing that behavioral intention has an influence on use behavior. Behavioral Intention in use technology is defined as a person's desire to perform a certain behavior. Indicators used to measure behavioral intention are: attitudes toward behavior and normative considerations to use the technology in the future.

H5 : The behavioral intention has significant effect on users behavior.

The idea of smart citizen is important in contributing to the urgent debate about the future of a city. An industry is developing around the vision of 'Smart City', estimated to be worth more than that $\$ 20$ billion of annual market value by 2020 (Pike, 2013). However, debating merely on the vision will not give citizens the economic benefits that they claim (Pike, 2013). Thought of smart citizen as a co-creator refers to a rich intellectual background in both technology design and urban design (Pike, 2013). Digital culture has spawned collaborative code ethics, and there has been a tendency to apply thought and methods from open source software development to other domains (Giffinger, 2007). This idea resonates with the tradition in urban planning that was first articulated by Patrick Geddes (Pike, 2013) at the turn of the 20th century, and held by Jane Jacobs in the 1960s when he demanded that institutional city planning make room for the voices and views of citizens.

The concept of smart citizen is a platform to generate participatory processes of people in the city. Connecting data, people and knowledge to serve as a node in building productive and open indicators, and distributed tools for the collective development of the city. Smart citizen needs to be realized by members of the government and also the entire community to build a good country with good governance as well and not left behind in development. Table 1 below enumerates the characterictics of a smart citizen in terms of the behavioral intention and user behavior (Giffinger et.al., 2007); (Handiawan, 2017). 
Table 1. The characteristic of Smart Citizen

\begin{tabular}{|l|l|}
\hline \multicolumn{1}{|c|}{ Behavioral Intention } & \multicolumn{1}{c|}{ User Behavior } \\
\hline Affinity to long life learning & Active \\
\hline Open Mindedness & Flexibility \\
\hline Social and Ethnic Plurality & Participation in public life \\
\hline Level of Qualification & Be Cooperative \\
\hline & Express opinion \\
\hline & Self Control \\
\hline & Creativity \\
\hline
\end{tabular}

Source: Data compiled by the author (Fridayani, 2018)

\section{RESEARCH METHOD}

The research method is basically a scientific way to get the data with a specific purpose and usefulness. This study uses a mixed method of both quanlitative and qualitative research techniques. Quantitatively, the study connects variables using the SmartPLS the method of Structural Equity Models with AMOS techniques. This quantitative approach is based on the philosophy of positivism, examining a particular population or sample, data collection using quantitative/statistical data analysis, with the aim to test the predefined hypothesis (Sugiyono 2016: 11). For the qualitative method, the researchers conducted interviews with several respondents from government which is department of communication and information and the community which ever use the lapor sleman mobile application. The qualitative approach refers to the meanings, concepts definitions, characteristics, metaphors, symbol, and description of the things to compliment the quantitative data (Sugiyono, 2016). The researchers distributed questionaires, after validity and reliability test were undertaken to a total of 100 respondents. The unit of analysis refers to the level of data units collected during the data analysis stage (Sekaran, 2007:173). In this case, the unit of analysis is individual. Data was collected in one period, then it was processed, analyzed and then drawn in conclusion. Hence, this research used cross-sectional method (Indrawati, 2015:118).

Data collection involved both the primary and secondary data. According to Sekaran and Bougie (2010:180), primary data refers to the information gained first-hand by researchers related to the interest variables for specific study purposes. The primary data in this study are obtained through questionnaires and indepth interviews conducted from May to June 2018. On the other hand, the secondary sources of data collection 
which refers to information collected from the existing sources (Sekaran and Bougie, 2010:180) included reviews of related literatures, journals, researches, articles, and other electronic resources relevant to the study. In this paper, the researchers used probability sampling technique from the 1,500 potential respondents based on the number of population associated with the daily use of lapor sleman every years around 1500 complaints. More specifically, the type of probability sampling technique used in this study is the purposive sampling of the citizens using the lapor sleman application in Sleman regency with solvin formula that is found 100 respondents.

\section{RESEARCH FINDINGS}

Smart regency does not only requires good technology and good governance, but also need support system from the community called smart citizens. Smart regency will be created, if there are smart citizens who maximize technology use. The technological applications which are created and updated by the government in order to realize the smart regency will be useless, if not supported by the people who are consciously using technology in Sleman. That is why citizens behavior towards using technology is an important factor in making smart citizens.

At this juncture, the convergent validity test, discriminant validity test results, reability test and hypothesis testing are summarized in the path coefficients table presented in figure 2 and table 2 , respectively.

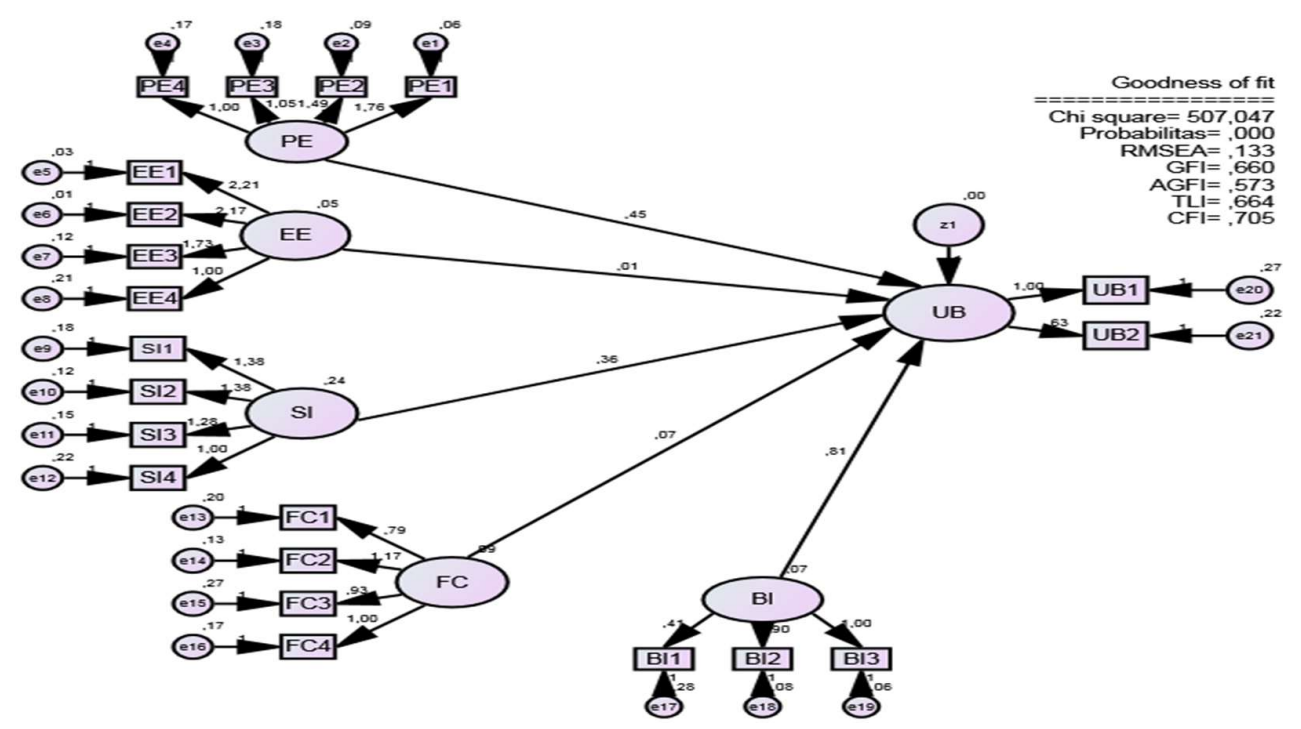

Figure 2. Hypothesis testing. Source: Figure from SmartPLS 2.0., 2018. 
Table 2. Hypothesis Test Result

\begin{tabular}{|c|l|c|c|c|c|l|}
\hline Hypothesis & Lane & $\begin{array}{c}\text { Lane } \\
\text { Coefficie } \\
\text { nt }\end{array}$ & $\begin{array}{c}\text { The Line of } \\
\text { Influence }\end{array}$ & $\begin{array}{c}\boldsymbol{P} \\
\text { value } \\
\text { (Sig) }\end{array}$ & Information & Conclusion \\
\hline H1 & PE->UB & 0,450 & $(+)$ & 0,031 & Significant & Supported \\
\hline H2 & EE->UB & 0,005 & $(+)$ & 0,984 & Not Significant & Rejected \\
\hline H3 & SI->UB & 0,365 & $(+)$ & 0,008 & Significant & Supported \\
\hline H4 & FC->UB & 0,067 & $(+)$ & 0,790 & Not Significant & Rejected \\
\hline H5 & BI- $>$ UB & 0,815 & $(+)$ & 0,011 & Significant & Supported \\
\hline
\end{tabular}

Source: The data is compiled by primary data, 2018 .

It can be seen that in $\mathrm{H} 1$ line the path coefficient has a positive influence direction of 0.450 and is significant because the significance value ( $p$ value) $=0.031$ is less than 0.05 , so it can be said that performance expectancy has a positive and significant effect on users behavior, which means if performance expectancy increases or increases by one unit, then user behavior increases or increases by 0.450 assuming the other independent variables remain or equal to zero, so it can be concluded that $\mathrm{H} 0$ is rejected and $\mathrm{Ha}$ is accepted, which means that performance expectancy has a significant effect on users behavior. Based on these results, the first hypothesis of this study is accepted or proven

In line $\mathrm{H} 2$, the path coefficient has a positive influence direction of 0.005 and is not significant because the significance value $(\mathrm{p}$ value $)=0.984$ is greater than 0.05 , so the effort expectancy has a positive and insignificant effect on users behavior, which that is, if effort expectancy increases or increases by one unit, then users behavior does not increase or increases by 0.005 assuming the other independent variables remain or equal to zero, so it can be concluded that $\mathrm{HO}$ is accepted and Ha is rejected, which means that effort expectancy has no significant effect against users behavior. Based on these results, the second hypothesis of this study was rejected or not proven.

At line H3, it can be seen that on the H3 line the path coefficient has a positive influence direction of 0.365 and is significant because the significance value ( $p$ value) $=$ 0.008 is smaller than 0.05 , so social influence can be positively and significantly affected on users behavior, which means if social influence increases or increases by one unit, then user behavior increases or increases by 0.365 assuming the other independent variables remain or equal to zero, so it can be concluded that $\mathrm{HO}$ is rejected and $\mathrm{Ha}$ is accepted, which means that social influence has a significant effect on users 
behavior. Based on these results, the third hypothesis of this study is accepted or proven.

On the H4 line, shows that on the H4 line path coefficient has a positive influence of 0.067 and is not significant because the significance value ( $p$ value) $=$ 0.790 is greater than 0.05 , so facilitating condition can be positively and insignificantly affected to users behavior, which that is, if the facilitating condition increases or increases by one unit, then the user behavior does not increase or does not increase by 0.067 assuming another independent variable remains or equals zero, so it can be concluded that $\mathrm{HO}$ is accepted and $\mathrm{Ha}$ is rejected, which means that facilitating condition has no significant effect against users behavior. Based on these results, the fourth hypothesis of this study is rejected or not proven.

At line H5, shows the path coefficient has a positive influence direction of 0.815 and is significant because the significance value ( $\mathrm{p}$ value) $=0.011$ is smaller than 0.05 , it can be stated that intention behavior has a positive and significant effect on users behavior, which means if Intention behavior increases or increases by one unit, then users behavior increases or increases by 0.815 with the assumption that the other independent variables remain or equal to zero, so it can be concluded that $\mathrm{H} 0$ is rejected and $\mathrm{Ha}$ is accepted, which means that the intention behavior has a significant effect on users behavior. Based on these results, the fifth hypothesis of this study is accepted or proven.

Based on the findings and analysis of the the hypotheses' testing, here is the proposed model made by the authors for citizens behavior of using lapor sleman mobile application to build the smart citizen. The model results in this study there are several independent variables that have no significant effect on the dependent variable, so to obtain the results of the research model that meets the goodness of fit must be made a new model called the proposed model. Proposed model is created by eliminating the lines of independent variables that do not have a significant effect on the dependent variable, as well as an invalid indicator of independent variables. 


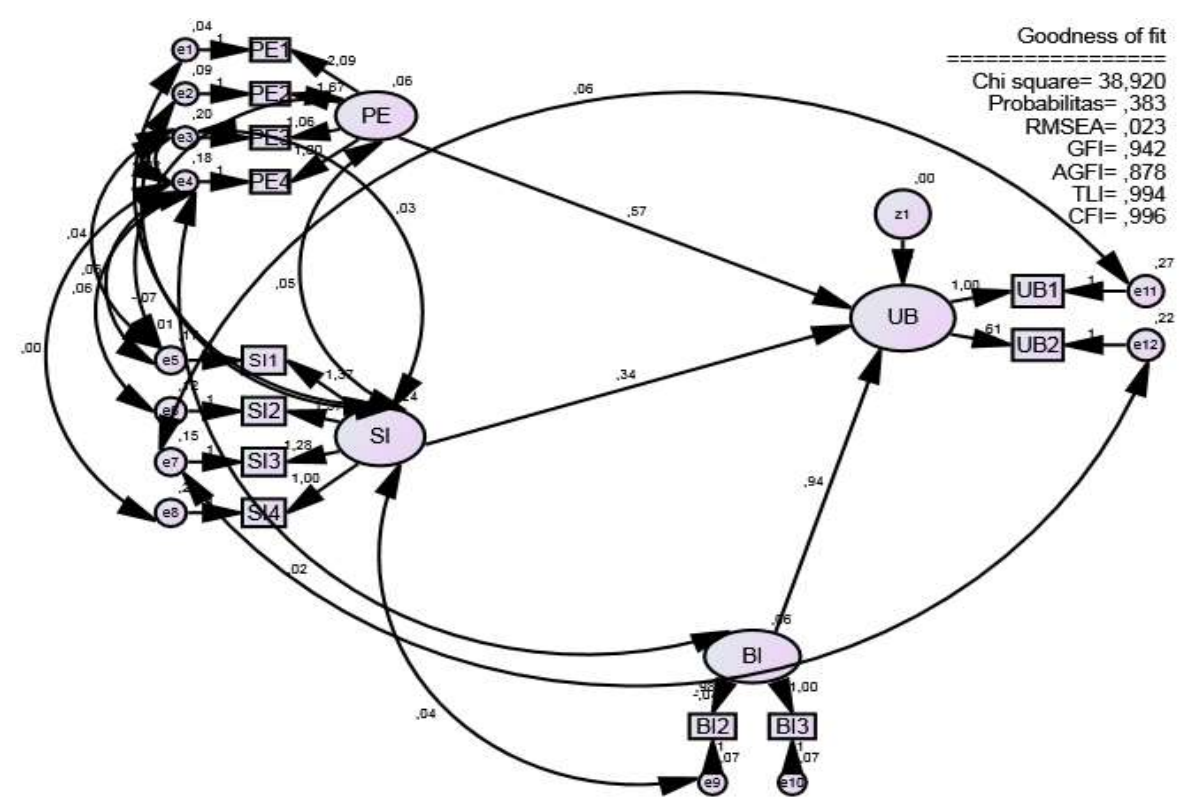

Figure 3. Research Proposed model (Re-test of Goodness and Fit Model)

Source: Figure from Amos 21 Version., 2018.

Table 3. Model Fitness re-test for the Proposed Model

\begin{tabular}{|l|l|l|c|c|}
\hline No & Criteria & Cut off value & Estimation Result & Conclusion \\
\hline 1 & Chi square $\left(X^{2}\right)$ & $\begin{array}{l}\text { Small } \\
\text { Expected }\end{array}$ & 38,920 & - \\
\hline 2 & Probability $(p)$ & $\geq 0,05$ & 0,383 & Fit \\
\hline 4 & GFI & $\geq 0,90$ & 0,942 & Fit \\
\hline 5 & AGFI & $\geq 0,90$ & 0,878 & Good \\
\hline 6 & CFI & $\geq 0,95$ & 0,996 & Fit \\
\hline 7 & RMSEA & $\leq 0,08$ & 0,032 & Fit \\
\hline 8 & TLI & $\geq 0,95$ & 0,994 & Fit \\
\hline
\end{tabular}

Source: This data is compiled by the primary data, 2018 .

Despite the failure of the research model to pass the indices required for the good-model fit test, it should be noted that the relationships of the variables and the coefficient of determination are worth considering. As discussed in the preceding parts of the research, the variable of performance, social influence, and behavioral intention have significant effect of users behavior. Effort Expectancy and facilitating condition however, was revealed to have no significant relationship with users behavior.

In the model construction, it must be cautiously considered how a researcher must arrive with a model that would meet all fit indices without sacrificing the 
relationships of the predictor variables to the other variables. The independent/predictor variables in this model are performance expectancy, social influence, behavioral intention while the dependent variables are the users behavior. Results of the study shows that there are independent variables that have no significant effect on the dependent variable, so to obtain the results of the research, the authors constructed a model that meets the goodness of fit based on 8 models of the tests.

\section{DISCUSSION}

The preceding discussion revealed the results of the nine hypotheses. Findings show that performance expectancy has a positive effect of 0.450 and is significant ( $p$ value $=0.031<0.05)$ to users behavior, which means if the performance expectancy increases or increases by one unit, then the user behavior increases or increases by 0.450 assuming the other independent variables remain or equal to zero, so the first hypothesis in this study is accepted or proven. This shows that the higher the performance of one's expectancy, the higher the user behavior. Performance expectancy has a positive and significant effect on users behavior in accordance with the results of research from Yang, et.al., (2007); Song, et. al., (2008), and Qian, et. al., (2008) which revealed that performance expectancy is one of the constructs of UTAUT which has a significant positive effect on user behavior. This means that the better the performance of the technology according to the expectations of the user, the more likely the interest in using the technology by the user is also higher.

The results of the second hypothesis test in this study indicate that effort expectancy has a positive effect of 0.005 and is not significant ( $p$ value $=0.984>0.05$ ) to users behavior, which means if the effort expectancy increases or one unit, then the user behavior does not increase by 0.005 assuming the other independent variables remain or equal to zero, so the second hypothesis in this study is rejected or not proven. This shows that an ups and downs or a high or low effort expectancy of the government cannot affect users behavior. These results are in line with the results of research from Taiwo et al. (2013), Tibenderana \& Ogao (2008); Qian, et. al., (2008), and Šumak, Polančič \& Heričko (2010) which concluded that effort expectancy had no significant effect on users behavior. 
The results of the third hypothesis testing in this study indicate that social influence has a positive effect of 0.365 and significant ( $\mathrm{p}$ value $=0.008<0.05$ ) on users behavior, which means that if social influence increases or increases one unit, then user behavior increases or increases by 0.365 assuming the other independent variables remain or equal to zero, so the third hypothesis in this study is accepted or proven. This means high and low social influence from other parties, causing significant changes in one's users behavior. The results of this study are supported by the results of research from Yang, et.al., (2007) which states that social influence has a significant effect on users behavior.

The results of the fourth hypothesis in this study indicate that facilitating condition has a positive effect of 0.067 and is not significant ( $p$ value $=0.790>0.05$ ) for users behavior, which means that if the facilitating condition increases or increases by one unit, then the user behavior does not increase or not increased by 0.067 assuming the other independent variables remain or equal to zero, so the fourth hypothesis in this study is rejected or not proven. This shows that the good and bad facilitation of existing conditions does not have a significant effect on users behavior. These results are consistent with the results of research conducted by Maldonado, Khan, Moon and Rho (2009) which found that facilitating conditions did not significantly influence users behavior.

The results of the fifth hypothesis test in this study indicate that the behavior intention has a positive effect of 0.815 and is significant ( $\mathrm{p}$ value $=0.011<0.05$ ) to users behavior, which means that if the intention behavior increases or increases one unit, then the user behavior increases or increases by 0.815 assuming the other independent variables remain or equal to zero, so the fifth hypothesis in this study is accepted or proven. This shows that if the intention behavior is higher, then the user behavior will be higher, on the contrary if the behavior intention is lower, then the user behavior tends to be lower. This means that intention behavior has a positive and significant effect on users behavior. These results are consistent with the results of previous studies from $\mathrm{He} \& \mathrm{Lu}$ (2007), as well as Maldonado et al. (2009) which revealed that behavior intention had a significant effect on user behavior.Figure 5 . The factors affected the user behavior in using Lapor Sleman Application to build the Sleman Smart Citizen. 
Table 4. The Proposed Model Affected of Using Lapor Sleman Mobile Application to build Sleman Smart Citizen

\begin{tabular}{|c|l|c|c|c|l|l|}
\hline Hypothesis & Lane & $\begin{array}{c}\text { Lane } \\
\text { Coefficien } \\
\mathbf{t}\end{array}$ & $\begin{array}{c}\text { Influen } \\
\text { ce Line }\end{array}$ & $\begin{array}{c}\text { P value } \\
\text { (Sig) }\end{array}$ & Information & Conclusion \\
\hline H1 & PE->UB & 0,568 & $(+)$ & 0,016 & Significant & Supported \\
\hline H2 & SI->UB & 0,335 & $(+)$ & 0,013 & Significant & Supported \\
\hline H3 & BI->UB & 0,943 & $(+)$ & 0,003 & Significant & Supported \\
\hline
\end{tabular}

Source: This data compiled by the author, (Fridayani, 2018).

H1 shows that expectancy performance variable has a positive path coefficient of 0.568 and is significant because the significance value ( $p$ value) $=0.016$ is smaller than 0.05 , so it can be said that the performance expectancy has a positive and significant effect on users behavior, which means if the performance expectancy increases or increases by one unit, then users behavior increases or increases by 0.568 assuming the other independent variables remain or equal to zero. Based on these results, the first hypothesis of the proposed research model is accepted or proven.

The H2 line shows the social influence variable has a positive path coefficient of 0.335 and is significant because the significance value ( $\mathrm{p}$ value) $=0.013$ is smaller than 0.05 , so social influence can be said to have a positive and significant effect on users behavior, which means if social influence increases or increases by one unit, then the user behavior increases or increases by 0.335 assuming the other independent variables remain or equal to zero. Based on these results, the second hypothesis of the proposed research model is accepted or proven.

Line H3 shows the intention behavior variable has a positive path coefficient of 0.943 and is significant because the significance value ( $\mathrm{p}$ value $)=0.003$ is smaller than 0.05 , it can be said that intention behavior has a positive and significant effect on users behavior, which means if the behavior intention increases or increases by one unit, then users behavior increases or increases by 0.943 assuming the other independent variables remain or equal to zero. Based on these results, the third hypothesis of the proposed research model is accepted or proven.

The most dominant independent variables influencing users behavior in the proposed model is the behavioral intention variable because it has the greatest influence path coefficient of 0.943 , compared with the performance expectancy path coefficient $=$ 0.568 , and social infleunce $=0.335$. This means that $94.3 \%$ of changes that occur in users behavior variables are influenced or can be explained by the variable intention behavior.

This finding implies (Batara, 2017) that the regency government employees and the citizens believe that using Lapor Sleman mobile application can or have already met their expectation in term of performance, especially to build the smart citizen in Sleman. In addition, this means that giving criticism of the UTAUT theory (Vankatesh, 2003), not all the four independent variables influence behavioral intention and user behavior 
of using technology in Sleman regency. The findings of the study provides an illustration that only three independent variables namely performance expectancy, social influence, and facilitating conditions have significant effects as indicators in technology use of making smart citizens, as essential component of a smart city. Unlike with this study that facilitating condition has no significant effect on user behavior.

In addition to this, facilitating conditions in Sleman apparently cannot directly affect the user behavior. Unlike the UTAUT theory (Vankatesh, 2003) which states that facilitating conditions directly affect of user behavior. All independent variables received are performance expectancy, social influence, and behavioral intention affecting the users behavior. Besides, performance expectancy can directly affect on user behavior. In accordance with the results of interviews which stated that the community believed that with the government's efforts to improve the quality of public services and shown by better performance, the longer the community increasingly trusted the government and wanted to use the Sleman Report application and the longer it would be a continuing behavior done and finally advanced using technology. Then, agree with the UTAUT theory (Vankatesh, 2003) that behavioral intention will automatically influence user behavior. When there is intention and willingness to use a technology, the longer it will become a habit and behavior.

As mentioned before, the most dominant independent variables influencing users behavior in the proposed model is the intention behavior variable because it has the greatest influence path coefficient of 0.943, compared with the performance expectancy path coefficient $=0.568$, and social infleunce $=0.335$. This means that $94.3 \%$ of changes that occur in users behavior variables are influenced or can be explained by the variable intention behavior.

This means that giving criticism of the UTAUT theory (Vankatesh, 2003), that not all independent variables of influence user behavior of using technology in Sleman. The case in Sleman Regency provides an illustration that only 3 independent variables can be accepted as indicators that affect the use of technology, namely performance expectancy, social influence, and also behavioral intention. In addition to this, facilitating conditions and also effort expectancy in Sleman apparently cannot affect the user behavior. Unlike the UTAUT theory (Vankatesh, 2003) which states that facilitating conditions and effort expectancy directly affect on user behavior. All independent variables received are performance expectancy, social influence, behavioral intention affecting the users behavior. In accordance with the results of interviews which stated that the community believed that with the government's efforts to improve the quality of public services and shown by better performance, the longer the community increasingly trusted the government and wanted to use the Lapor Sleman application and the longer it would be a continuing behavior done and finally advanced using technology. Then, agree with the UTAUT theory (Vankatesh, 2003) that behavioral intention will automatically and the biggest influence user behavior. When there is intention and willingness to use a technology, the longer it will become a habit and behavior.

As explained above, social influence has smallest influences people to use technology to reach smart citizens if there is someone, or even the community that 
advises and informs the application of Lapor Sleman. In order to achieve smart citizens need support from all parties, including the government, the private sector, and the community must work together in realizing this. Based on the results of the interview, it is also said that the community actually wants to use it if there is a socialization, and the learning to use the Lapor Sleman application in Sleman.

In addition, smart citizens have the characteristics of flexibility, activeness in expressing opinions providing the community and the government on how regional development should proceed. Subsequently, it will result to good cooperation between the government and the community to realize smart citizens in smart regency. It can be conclude that from use behavior of using technology, and from this study of the three independent variables that received the smart citizens in Sleman Regency. Therefore people in Sleman can be categorized as a quite good citizen, and become the smart citizen. Judging from the theory of Giffinger at al. (2007) and Hendiawan (2017) above, with a good performance, social influence and behavioral intention, a smart citizen is in the making in Sleman regency.

Hence, smart regency will be created, if there are smart citizens. The mobile application that have been created and updated in such a way by the government in order to realize the smart regency will be useless if not supported by the people who are consciously using technology for support in Sleman. It would be meaningless, if the applications implemented by the government to facilitate the community actually would not be readily available and accessible to the community.

\section{IMPLICATION TO THEORY}

In the context of this study and from the government employees' department of communication and information and also the community perspective, social influence, and facilitating condition are the povital or dominant variable in the intention to use the lapor sleman mobile application (Table 4). This supports the argument that social influence which they have a positive affect (Foon and Fah, 2011; Indriwati and Haryoto, 2013; Venkatesh, 2013, Xu, 2014), on user behavior to use technology. Besides, the performance expectancy also has emerge as predictor of the particular users behavior. Effort expectancy does not emerge as the predictors of the user behavior, thus not advancing support to the prevailing notions of many studies. This finding implies that both of government and community already believe that using the lapor sleman mobile application can or have already met their expectation in term of build the smart citizen. The findings support the generally validated models which report the performance expectancy, social indluence, and behavioral intention (Lin and Liang, 2011; Carter, et. al., 2012; Weerakkody, at.al., 2013) are predictor variables of the building smart citizen adoption through the citizen behavior.

Performance expectancy, social influence, and behavioral intention are pivotal predictors of the intention to adopt process for build the smart citizen. For this particular dimention, both of government and citizens view positive impacts on performance and external factors as the important reasons to build the smart citizen. An interesting finding in this aspect is that the effort expectancy and facilitating condition has negatively influence on the users behavior. As seen the validated research model, this 
study has shown that such constructs' roles as predictors (Performance expectancy, social influence, and behavioral intention) of users behavior can be measure to other dimensions of smart citizen. This is the evident contribution of this research to the smart citizen adoption literature: the examination and validation of the constructs' roles in the aspect of building the smart citizen.

\section{LIMITATIONS AND FUTURE RECOMMENDATIONS}

Appropriate provisions have been carried out by the researchers in the conduct of this study, but certain limitations need to be considered with regard to the interpretation of its findings. First, the determination of the sample size was done through purposive sampling, so the application of the results should be done with prudence. Future researchers must take note of the community population size, so that if it is just a small and manageable size, then complete enumeration would be ideal. The result could then be safely generalized to the whole population. Second, the constructs used for the research model were chosen due to their prominence in the literature. Future researchers may consider investigating other variables or developing constructs which are appropriate in both of government and community context. Future researchers could frame other measures deemed to be approriate for the constructs. Then, this study made use of a simple linear regression model in hypothesizing the relationships of the constructs and therefore future research may develop research models that would explore some other nuances in the constructs' relationships. Future research may consider including other variables.

Moreover, here the reccomendation of the research. Firstly, the Lapor Sleman application must be updated with a more efficient system, which provides easy access for the intended users. Secondly, the government must do information and educational campaigns (IECs) to disseminate the use of sleman report application technology towards realizing the smart citizen concept in Sleman regency. Lastly, performance expectancy, social influence, and facilitating conditions should be enhanced to increase smart citizens' participation. This is due to the fact that in the past 2 years, 2016-2018 smart citizens in Sleman Regency have been seen, but have not shown significant or not yet maximum results. So, that in 2021 it can be realized Sleman smart citizen requires maximization in the context of performance expectancy, which makes the community more confident in using the Lapor Sleman application as a means to improve public services. Related to social influence, the government must provide socialization and give the influence to the community to encourage the use the Lapor Sleman application. Lastly, for the facilitating conditions, the government must provide internet network infrastructures that are sufficient to access the application, and not only on smartphones in the form of android but also available for IOS users such as the iPhone to increase application users of Lapor Sleman.

\section{CONCLUSION}

The citizens behavior of using technology in Sleman are influenced by three variables namely; perfomance expectancy, social influence, also the behavioral intention. The applications that have been created and updated in such a way by the government in order to realize the smart regency will not be meaningless if not 
supported by the people that conscious about the using technology for support the smart regency in Sleman. It would be very useless if the applications implemented by the government to facilitate the community actually even complicate the community considering the most important component of the success of smart city is support from citizen that ones is using the technology. Judging from the theory of Giffinger at al. (2007) and Hendiawan (2017) above, with a good performance, social influence and facilitating conditions, a smart citizen will be reached. Therefore, it can be seen that of the three independent variables that received which are performance expectancy, social influence, and facilitating conditions all is good, the smart citizens in Sleman Regency can be categorized as quite good and just improve the system of the application to make the Sleman smart citizen realize on 2021.

\section{REFERENCES}

Aelenei, Laura et al. (2016). "Smart City: A Systematic Approach towards a Sustainable Urban Transformation." Energy Procedia 91: 970-79. http://dx.doi.org/10.1016/j.egypro.2016.06.264.

Ahvenniemi, Hannele, Aapo Huovila, Isabel Pinto-Seppä, and Miimu Airaksinen. (2017). "What Are the Differences between Sustainable and Smart Cities?" Cities 60: 234-45. http://dx.doi.org/10.1016/j.cities.2016.09.009.

Allwinkle, Sam, and Peter Cruickshank. (2011). "Creating Smart-Er Cities: An Overview." Journal of Urban Technology 18(2): 1-16.

Alkhunaizan, A. M., \& Love, S. (2012). What drives mobile commerce? An empirical evaluation of the Revised UTAUT Model. International Journal of Management and Marketing Academy, 2(1), 82-99. Retrieved February 13, 2017, from http://marcomacademy.co.uk/ijmma/What-drives-mobile-commerce-Anempirical-evaluation-of-the-revised-UTAUT-model.pdf

Alshehri, M. A. (2012). Using the UTAUT model to determine factors affecting acceptance and use of e-government services in the kingdom of Saudi Arabia. Griffith University.

Attuquayefio, S., \& Addo, H. (2014). Using the UTAUT model to analyze students' ICT adoption. International Journal of Education and Development using ICT, $10(3)$.

Baldascino, Mauro, and Michele Mosca. (2016). "The Capability Approach and the Tools of Economic Policies for Smart City." Procedia - Social and Behavioral Sciences 223: 884-89. http://linkinghub.elsevier.com/retrieve/pii/S1877042816303858.

Batara, E., Nurmandi, A., Warsito, T., \& Pribadi, U. (2017). Are government employees adopting local e-government transformation? The need for having the right attitude, facilitating conditions and performance expectations. Transforming Government: People, Process and Policy, 11(4), 612-638.

Bickerstaff, K. and G. Walker (2005) Shared Visions, Unholy Alliances: Power, Governance and Deliberative Processes in Local Transport Planning. Urban Studies 42(12): 2123-2144.

Bull, R., J. Petts, et al. (2008) Social Learning from Public Engagement: Dreaming the impossible? Journal of Environmental Management and Planning 51(5): 703-718. 
Bull, R. J., J. Petts, et al. (2010) The Importance of Context for Effective Public Engagement. Journal of Environmental Planning and Management 53(8): 9911009.

Carrillo, Francisco Javier. (2006). Knowledge Cities: Approaches, Experiences and Perspectives. Routledge.

Cocchia, Annalisa. (2014). Smart City. http://link.springer.com/10.1007/978-3-31906160-3.

Creswell, J. W., \& Clark, V. L. P. (2017). Designing and conducting mixed methods research. Sage publications.

D’Aniello, Giuseppe, Matteo Gaeta, and Francesco Orciuoli. (2017). “An Approach Based on Semantic Stream Reasoning to Support Decision Processes in Smart Cities." Telematics and Informatics (July): 0-1. http://dx.doi.org/10.1016/j.tele.2017.09.019.

Deakin, Mark, and Husam Al Waer. (2011). "From Intelligent to Smart Cities." Intelligent Buildings International 3(3): 140-52.

Dwiratry. Elvandari (2011). Penerimaan Sistem Online Shopping berdasarkan Unified Theory of Acceptance and Usage of Technology. Integra, 1(1).

Foon, Y. S., \& Fah, B. C. (2011, April). Internet Banking Adoption in Kuala Lumpur: An Application of UTAUT Model. International Journal of Business and Management, 6(4), 161-167. doi:http://dx.doi.org/10.5539/ijbm.v6n4p161

Garcia-Ayllon, Salvador, and Jose Luis Miralles. (2015). "New Strategies to Improve Governance in Territorial Management: Evolving From 'smart Cities' to 'smart Territories."” Procedia Engineering 118: 3-11.Ghozali, Imam. (2006). Aplikasi Analisis Multivariate Dengan Program SPSS. Cetakan Keempat. Semarang: Badan Penerbit Universitas Diponegoro.

Giffinger, R., Fertner, C., Meijers, E., \& Kramar, H. (2007, January). Smart cities Ranking of European medium sized sized. Retrieved February 11, 2017, from https://www.researchgate.net/publication/261367640_Smart_cities__Ranking_of_European_medium-sized_cities

Gupta, B., S. Dasgupta and A. Gupta. (2008). Adoption of ICT in a government organization in a developing country: An empirical study", Journal of Strategic Information Systems, 17: 140-154.

Hollands, Robert G. (2008). "Will the Real Smart City Please Stand up? Intelligent, Progressive or Entrepreneurial?" City 12(3): 303-20.

Holler, Jan et al. (2014). "Smart Cities." From Machine-To-Machine to the Internet of Things: 281-94. http://linkinghub.elsevier.com/retrieve/pii/B9780124076846000140.ITU. (2017). "Focus Group on Smart Sustainable Cities." http://www.itu.int/en/ITUT/focusgroups/ssc/Pages/default.aspx (March 24, 2017).

Indrawati. (2015). Metode Penelitian Manajemen Dan Bisnis Konvergensi Teknologi Komunikasi dan Informasi. (D. Sumayyah, Ed.) Bandung: PT Refika Aditama.

Indrawati, \& Haryoto, K. S. (2015, August 11-15). The Use of Modified Theory Acceptance and Use of Technology 2 To Predict Prospective Users' Intention in Adopting TV Streaming. Proceedings of the 5th International Conference on Computing and Informatics, ICOCI 2015, 125, 206-215. Retrieved February 19, 2017, from http://www.icoci.cms.net.my/proceedings/2015/PDF/PID125.pdf

Indrawati, \& Marhaeni, G. A. (2015). ANALISIS PERILAKU PENGGUNAAN APLIKASI PESAN INSTAN DENGAN MENGGUNAKAN MODEL UNIFIED 
THEORY OF ACCEPTANCE AND USE OF TECHNOLOGY 2 DI KOTA BANDUNG. Telkom University Journal. Retrieved Mei 15, 2017, from https://www.google.co.id/url?sa=t\&rct=j\&q=\&esrc $=$ s\&source=web\&cd $=1 \& c a d=r$ ja\&uact

$=8 \& v e d=0$ ahUKEwjBlfag1PHTAhWHuY8KHQA9BPUQFggmMAA\&url=https $\% 3 \mathrm{~A} \% 2 \mathrm{~F}$

$\% 2$ Frepository.telkomuniversity.ac.id\%2Fpustaka\%2Ffiles\%2F65614\%2Fjurnal_ eproc $\% 2$ Fanalisis-perilaku-penggunaan-aplik

Jogiyanto, Hartono. (2004). Metodologi Penelitian Bisnis, Edisi 2004-2005. BPFE. Yogyakarta.

Joshi, Sujata, Saksham Saxena, Tanvi Godbole, and Shreya. (2016). "Developing Smart Cities: An Integrated Framework." Procedia Computer Science 93(September): 902-9. http://dx.doi.org/10.1016/j.procs.2016.07.258.

Jucevicius, Robertas, Irena Patasiene, and Martynas Patasius. (2014). "Digital Dimension of Smart City: Critical Analysis." Procedia - Social and Behavioral Sciences 156(April): 146-50. http://linkinghub.elsevier.com/retrieve/pii/S1877042814059576.

Kourtit, Karima, Peter Nijkamp, and John Steenbruggen. (2017). "The Significance of Digital Data Systems for Smart City Policy.” Socio-Economic Planning Sciences 58: 13-21. http://dx.doi.org/10.1016/j.seps.2016.10.001.

Lee, Jung Hoon, Marguerite Gong Hancock, and Mei Chih Hu. (2014). "Towards an Effective Framework for Building Smart Cities: Lessons from Seoul and San Francisco." Technological Forecasting and Social Change 89: 80-99. http://dx.doi.org/10.1016/j.techfore.2013.08.033.

Letaifa, Ben Soumaya. (2015). "How to Strategize Smart Cities: Revealing the SMART Model." Journal of Business Research 68(7): 1414-19. http://dx.doi.org/10.1016/j.jbusres.2015.01.024.

Kalnadi, D. 2013. Pengukuran Penerimaan dan Penggunaan Teknologi Pada UMKM Dengan Menggunakan Metode UTAUT. Jurusan Adm.Bisnis, Fakultas ISIP, Universitas Lampung.

Marsal-Llacuna, Maria Lluïsa, and Mark Evan Segal. (2016). "The Intelligenter Method (I) for Making 'smarter' City Projects and Plans.” Cities 55: 127-38.

Massana, Joaquim et al. 2017. "Identifying Services for Short-Term Load Forecasting Using Data Driven Models in a Smart City Platform." Sustainable Cities and Society 28: 108-17.

Mckinsey and Company. (2017). Praktik Good Governance dan smart city di Tujuh Negara Asia.

Moleong, L. J. (2007). Metodologi penelitian. Bandung: PT. Remaja Rosda Karya.

Monfaredzadeh, Tannaz, and Robert Krueger. (2015). "Investigating Social Factors of Sustainability in a Smart City." Procedia Engineering 118: 1112-18.

Nam, Taewoo, and Theresa A. Pardo. (2011). "Conceptualizing Smart City with Dimensions of Technology, People, and Institutions." Proceedings of the 12th Annual International Digital Government Research Conference on Digital Government Innovation in Challenging Times - dg.o '11: 282. http://dl.acm.org/citation.cfm?doid=2037556.2037602.

. (2011). "Smart City as Urban Innovation." 5th International Conference on Theory and Practice of Electronic Governance (ICEGOV2011): 185. https://www.scopus.com/inward/record.uri?eid=2-s2.0- 
$\underline{84855404899 \& \text { doi }=10.1145 \% 2 \mathrm{~F} 2072069.2072100 \& \text { partnerID }=40 \& \mathrm{md} 5=26 \mathrm{~d} 541}$ 09f4a18bfb68055fb0defbd3c3\%0Ahttps://www.ctg.albany.edu/publications/journ als/icegov_2011_smartcity/icegov_2011_smartcity.pdf\%0Ahttp://www. https://sustainabledevelopment.un.org/post2015/summit

Palomo, Navarro Alvaro, and Marco Julio Navio. 2017. "Smart City Networks' Governance: The Spanish Smart City Network Case Study." Telecommunications Policy (October): $1-9$. http://linkinghub.elsevier.com/retrieve/pii/S0308596117301507.

Pike Research "Smart Cities"
www.navigantresearch.com/research/smart-cities (accessed 01.08.2013).

(2013):

Praharaj, Sarbeswar, Jung Hoon Han, and Scott Hawken. (2017). "Innovative Civic Engagement and Digital Urban Infrastructure: Lessons from 100 Smart Cities Mission in India." Procedia Engineering 180: 1423-32. http://dx.doi.org/10.1016/j.proeng.2017.04.305.

Ricardo, Yohanes. 2012. Loyalitas Konsumen yang Dipengaruhi Oleh Suasana Toko dan Kualitas Pelayanan Melalui Kepuasan Konsumen. Jurusan Adm.Bisnis, Fakultas ISIP, Universitas Lampung.

Rosen, P. (2005). The effect of personal innovativeness on technology acceptance and use. PhD Thesis, Oklahoma State University.

Smart citizens for smart cities: Participating in the future (PDF Download Available). Available

from: https://www.researchgate.net/publication/302029638_Smart_citizens_for_smart_c ities_Participating_in_the_future [accessed Feb 02 2018].

Sovacool, B. (2014) What are we doing here? Analyzing fifteen years of energy scholarship and proposing a social science research agenda. Energy Research \& Social Science 1: 1-29.

Sugiyono. (2016). Metode Penelitian Kuantitatif, Kualitatif dan R\&D. Bandung: PT Alfabet.

Sutanta, Heri, Trias Aditya, and Retno Astrini. (2016). "Smart City and Geospatial Information Availability, Current Status in Indonesian Cities.” Procedia - Social and Behavioral Sciences 227(November 2015): 265-69. http://linkinghub.elsevier.com/retrieve/pii/S1877042816307558. https://www.theaseanpost.com/smartcity-in-asean.

Taiwo, A. A., \& Downe, A. G. (2013, January). The theory of user acceptance and use of technology (UTAUT): A meta-analytic review of empirical findings. Journal of Theoretical and Applied Information Technology, 49(1).

Travis, Charles. (2017). "GeoHumanities, GIScience and Smart City Lifeworld Approaches to Geography and the New Human Condition." Global and Planetary Change 156: 147-54. http://dx.doi.org/10.1016/j.gloplacha.2016.12.011.

Vanolo, Alberto. (2014). "Smartmentality: The Smart City as Disciplinary Strategy." Urban Studies 51(5): 883-98. http://journals.sagepub.com/doi/10.1177/0042098013494427.

Venkatesh, V. and F.D. Davis, (2013). A Theoretical the Technology Acceptance Model: Four Longitudinal Field Studies. Management Science, 46(2): 186-204.

$\mathrm{Vu}$, Khuong, and Kris Hartley. (2017). "Promoting Smart Cities in Developing Countries : Policy Insights from Vietnam.” Telecommunications Policy (October): 1-15. https://doi.org/10.1016/j.telpol.2017.10.005. 
Webler, Marx. (1995) "The Distribution of Power: Class, Status, Party”. Dalam Patrick Joyce (ed.). Class, Oxford: Oxford University Press

$\mathrm{Wu}$, Yuzhe et al. (2016). "Smart City with Chinese Characteristics against the Background of Big Data: Idea, Action and Risk." Journal of Cleaner Production: 1-7. http://dx.doi.org/10.1016/j.jclepro.2017.01.047.

Wu, M. Y., \& Liao, S. C. (2011). Consumers' behavioral intention to use internet shopping: an integrated model of TAM and TRA. Journal of Statistics and Management Systems, 14(2), 375-392.

Zygiaris, Sotiris. (2013). "Smart City Reference Model: Assisting Planners to Conceptualize the Building of Smart City Innovation Ecosystems." Journal of the Knowledge Economy 4(2): 217-31.

\section{Interview}

Adi. As the interviewees from community. Held on 5th august 2018 at 17.00 p.m.

Arifianto, Helmi. The head of the public communication and complaints service section Department of Comunnication and Information in Sleman Regency. Held on 11th august 2018 at 08.05 a.m

Ariya. The staff of the of the public communication and complaints service section Department of Comunnication and Information in Sleman Regency. Held on 30th July 2018 at 12.05 a.m

Burhan. As the interviewees from community. Held on 5th august 2018 at 10.10 a.m.

Mujiono. As the interviewees from community. Held on 5th august 2018 at 11.00 a.m.

Sumini. As the interviewees from community. Held on 5th august 2018 at 09.53 a.m.

\section{Website}

http://www.slemankab.go.id/profil-kabupaten-sleman/geografi/letak-dan-luas-wilayah accessed on August, 28th, 2018 at 6.37 p.m

http://www.slemankab.go.id/profil/profil-pemerintah-kabupaten-sleman/visi-dan-misi accessed on August, 30th, 2018 at 6.50 p.m

http://smartcities.id/ accessed on August, 30th, 2018 at 8.50 p.m

https://governmentinnovationawards.com/events/2017/information/innovationarcade.aspx accessed on August, 30th, 2018 at 9.03 p.m

https://id.techinasia.com/apa-itu-smart-city-dan-penerapan-di-indonesia accessed on August, 30th, 2018 at 9.23 p.m

http://sorot.id accessed on July 18, 2017.

http://jogja.tribunnews.com/2018/03/09/perlu-komitmen-untuk-menerapkan-smart-city on August, 30th, 2018 at 9.50 p.m written by Nova. 